\title{
Writing the Activist Novel
}

Alex Martin-Carey ${ }^{a *}$

${ }^{a}$ Faculty of Humanities, University of Kent, Canterbury, Kent, UK

*corresponding author: $\underline{\text { A.E.Martin-Carey@ Kent.ac.uk }}$

Alex Martin-Carey is a writer and theatre director. She is an Associate Lecturer in

Creative Writing and Drama at the University of Kent where she completed a PhD in

The Contemporary Novel. She also manages outreach projects for the university across

humanities subjects. Alex has written short stories and pieces for stage and film, and her debut novel The Greater Thief was published in 2012. 


\title{
Writing the Activist Novel
}

\begin{abstract}
:
Between The Wars is a novel based on the life and work of pacifist and social reformer Muriel Lester. An early member of anti-war organisation The Fellowship of Reconciliation, Lester was also a friend of Gandhi and a founder of East London church and community centre Kingsley Hall. Between The Wars is an interrogation of the beliefs that inspired her, the Christian pacifist movement she was a part of, and the challenge of living out the values of peace through two world wars. It is also an exploration of the relationship between activism and fiction, and the possibility of representing Lester's ideas in fictional form.
\end{abstract}

This paper examines the process of writing an activist novel that seeks change and yet allows, indeed encourages, the reader to question its beliefs, tracing the connections between the activism of Muriel Lester and the form and style of the novel she inspired.

Keywords: activism, writing process, novel form, creative writing, historical fiction

\section{Writing the Activist Novel}

My novel Between The Wars is a story about activism and may be an activist novel. Inspired by the life and work of Muriel Lester, it is an interrogation of the beliefs that inspired her, the Christian pacifist movement she was a part of, and the challenge of living out the values of peace through two world wars. The novel is also an exploration of the relationship between activism and fiction, and the possibility of representing Lester's ideas in fictional form. As I set out to write the life and activism of Muriel Lester into a novel, and to discover if such a novel could provoke change in its own 
right, I found that Muriel's activism began to make demands on the form and style of the novel. This article will examine the key implications of writing an activist novel that not only features Muriel Lester, but seeks to embody her ideas.

Muriel Lester was an early member of the Fellowship of Reconciliation, a faithbased anti war organisation founded in 1914. She later became a travelling secretary for the FOR's international branch, in which capacity she travelled the world meeting both the powerful and those fighting for peace and justice in volatile situations. She interpreted these conflicts and struggles for a wide audience through talks, books and articles. Muriel was also a lifelong champion of social reform and, with her sister Doris, spearheaded the creation of Kingsley Hall, a radical community centre and church in Bow which played host to Gandhi in 1931. She was influenced by a powerful ideological cocktail of political non-violence, radical Christianity, mysticism, her practical experience of social work in Bow and her friendship with people of the East End - all of which stood on the foundation of a privileged position and upbringing, and her prodigious talents as a storyteller.

Muriel herself defined her practice, somewhat grandly, as follows:

Our business is to stop war, to purify the world, to get it saved from poverty and riches, to heal the sick, to comfort the sad, to wake up those who have not yet found God, to create joy and beauty wherever you go, to find God in everything and everyone. (Lester 1942, 3)

This description makes plain the essential aspects of her philosophy: opposition to war ('stop war'); speaking out for justice ('purify the world'); working for social justice ('get it saved from poverty and riches, to heal the sick, to comfort the sad'); the spiritual and personal roots of peace ('wake up those who have not yet found God'); the artistic element of activism ('to create joy and beauty wherever you go'); and universal brotherhood ('to find God in everything and everyone'). 
The key idea which stands at the centre of Muriel's activism (and particularly activism for peace) is a connection between the practical and the ideological, illustrated for her by scripture and the figure of Christ. Muriel saw in Jesus a world-changing individual, the archetypal activist. For her the activist was to emulate Christ in two ways: specific acts of social justice (as Christ performs in the gospels), and in pointing beyond herself to larger truths (as Christ points beyond himself to the nature of God). In the Christian tradition this idea is known as incarnation. Christ is both fully God and fully human, God incarnate into human form, which means that 'Christ is a manifestation of the absolute within the setting of this world' (Collins 1966, 274). The activist (as with the follower of Jesus) is recognised by their presence and action within day-to-day life, as opposed to by statements of belief or purity customs. This same action points beyond themselves to what they believe. For Muriel incarnation was the model for powerful activism in which the activist themselves becomes the message.

Muriel's definition of activism also contains the imperative 'to create joy and beauty wherever you go'. Muriel saw that there was power in creativity, that art and activism were connected. She wrote that 'ours is to keep sensitive enough to be in contact with God daily, to practice life as an art' (Lester 1942, 10). This creativity, which was so characteristic of Muriel's understanding, also adds to our understanding of incarnation. God is understood as creator, and this creative God is manifest in and manifesting through Jesus in the process of incarnation. Christ both demonstrates and actually creates the new world order through his presence and actions for social justice. The activist then points to the idea through incarnation (being manifest in the world), but is also creating herself and the new world (manifesting through) in the process of incarnation, of living out conviction in the ordinary moments of life. Muriel often 
demanded change, but for her the real challenge was to 'practice life as an art'. To craft a life, and a mind, which embodied change in its habits and practices.

So the idea of incarnation suggested that the novel would need to represent Muriel's actions in a realistic material world in order to manifest her ideas effectively for readers. In doing so the form of the novel would mimic the form of her activism by focusing on the transformation of narrative moments through the person of the activist, which would also point beyond the narrative to an examination of her beliefs. After a degree of trial and error, experimenting with different voices, perspectives and modes of writing, I began to see Muriel and her world come to life most vividly through the voices of two narrators, Dorothy and George Hogg. However, I found a recurring desire to trouble the rather predictable storytelling of the kind of historical naturalism that simple incarnation suggested. Even in the early stages a desire crept into the characters' voices to amplify the meaning of their actions 'before our lives become only history' (Martin Carey 2016 5). They know that they are telling stories. They both discuss the role of writing within their practice of activism, and wrestle with the role of narrative, the politics of representation, and the relationship between truth and fiction. These struggles reflect central concerns of my own writing process, as I endeavoured to dissect the relationship between fiction, activism and propaganda. Something instinctive urged me to resist a narrative that was too simple, too clear, too cosy.

The more that elements of unreliability and heightened subjectivity crept into the narrative, the more I saw they reflected my own deepening understanding of Muriel. A more radical understanding of incarnation, and what Muriel meant by it, was necessary to formulate a clearer idea of the emerging aesthetics of the activist novel.

Muriel's view of incarnation (repeatedly enforced by stories from her own life) crucially acknowledged and incorporated the textual nature of scripture — that, as John 
Caputo (2001) explains using theories of theopoetics, a scriptural text 'admits of endless decontextualisation and decontextualisation, endless reading and rereading' (100). That 'God is a question, not an answer, the most radical thought we can entertain, that exposes the questionability of all other answers we think we have' (117). It is this Godquestion, then, who is incarnate in the story. This suggests a different way to think about incarnation. Rather than a single, narratively bound, 'manifestation of the absolute within the setting of this world', the text of scripture invites us to remember the 'scandal of particularity', or subjectivity, at the heart of the Jesus moment (Collins 1966, 274; 109). Despite its realistic cultural setting, the incarnation presented in the Gospels and the New Testament is a narrative unsettled by the subjective lens of individuality. This 'scandal' is hiding in plain sight once a nativity-play reading is cast off. Not only does Jesus express his ministry largely in acts and stories for, with, and towards a vast array of individuals, but the whole story is told through the radically different testimonies of four gospel writers (not withstanding the apocryphal gospels). These four writers take liberties with the material, have competing agendas, and in fact tell different versions of all the major stories. Incarnation then does not offer a concrete, realistic example. Instead of using naturalism to restrict, scripture presents an opportunity to engage in creative conversation. 'Its focal point is not Being but Becoming' (Underhill 2002, 24). This interpretation suggested to me an entirely more playful, and more radical, way of telling Muriel Lester's story.

Moreover, Muriel's definition of her activism includes the telling desire to 'wake up those who have not yet found God'. The verb 'wake up' suggests a break from traditional evangelism. Rather than teaching a set of values Muriel understood that her role was to facilitate a change of being in others, from resistant to change towards an open conversation. She did not understand incarnation to be the descent of God from a 
far away place into human form, but rather the ultimate expression of the God who is already 'in everything and everyone'. Her instruction to find God is better understood as an encouragement to see the divine. Incarnation demanded for Muriel a serious recognition of the divine in all, which was 'to learn to think like God [which] means to ignore barriers of class, race and nation ... the dropping of all labels' (Lester 1937, 27). To take this seriously means 'placing ourselves into question through the presence of the other' (Rollins 2012, 141).

I sought to reflect this more complex, subjective incarnation throughout Between The Wars. The novel, like Muriel, had to be rooted in its own questionability to avoid the danger of becoming propaganda. As well as revealing the writing process, as described above, and so their subjectivity, I wanted the characters to occupy a discursive world. They question themselves and others, and actively engage with ideas of activism, truth, and justice. The reader is invited to join Dorothy and George as they grapple with Muriel's philosophy. As Dorothy and George discover their own responses to her incarnation, they become their own, new, incarnate narrative of activism with whom the reader is also invited to engage and question. So there are three incarnations, triply subjective, allowing them to point together to a more complex idea. To avoid a sense that the reader is being directed, their two central stories move outwardly in opposite directions. George travels from confidence to uncertainty and Dorothy from uncertainty to confidence. Yet while these trajectories mirror one another they move across very different timeframes. The story is slippery, taking the characters and the reader by surprise in turning familiar tropes, settings, and characters on their heads.

Through an honest attempt to manifest Muriel's activist practice and philosophy into fiction I found that all certainties about the novel that resulted had dissolved. The idea of the activist novel that I discovered had to root in the fallibility of its own form if 
it was to become an activist novel in the spirit of Muriel Lester. As Muriel wrote in 1934, 'language is the means by which human beings misunderstand one another' (Lester 1934). I too had placed myself into question and had come to accept the possibility, indeed the almost inevitable fact, of the novel's failure to provoke quantifiable change. However, this no longer seemed an adequate measure for activism. The certainty and data that such an aspiration demands, such 'pretences at authoritative knowledge', can be seen as 'failures of language' (Solnit 2014, 88) in themselves, and certainly failures of imagination, or failures of narrative. In the essay on Virginia Woolf quoted above, Solnit suggests that Woolf's writing is always circling the unsayable, striving to value that which cannot be easily defined or quantified in order to preserve the very freedoms it wishes to promote. It is 'a revolt of the imagination, in favour of subtleties' (105). Here Solnit's reading of Woolf mirrors the activist novel inspired by Muriel Lester; both seek 'the digressive, the exploratory, the numinous, the uncertain' (105), because it is in all these places that the activist might find themselves or another can 'wake up'.

The activist works for change, of course, but like the artist she also keeps alive the possibility of another world. David Grossman (2007) has said: 'when we write we feel the earth move ... it is not frozen . . . there is no status quo'. In Muriel's philosophy it is never ultimately possible to change anything but oneself. It is this change of self that incarnation invites, and which holds the potential for all other change. The activist novel, then, must also be open to changing itself, open to question, uncertain and perhaps unreliable, so that even as it transforms the moments of it's own narrative it might open the door to some new question, some new or better view, and find, in turn, itself transformed to start the story afresh. 


\section{Bibliography}

Caputo, John. 2001. On Religion. London: Routledge.

Collins, Cannon L John. 1966. Faith Under Fire. London: Leslie Frewin.

Grossman, David. 2007. "PEN Freedom to Write Lecture”. April 29.

http://www.c-span.org/video/?198061-1/freedom-write-

Lester, Muriel. 1934. Writing in Harijan, March 30. Accessed via the Muriel Lester Archive, Bishopsgate Institute

Lester, Muriel. 1937b. Kill or Cure. Nashville: Cokesbury Press.

Lester, Muriel. 1942. Training. London: Independent Press Ltd.

Lester, Muriel. 1937. Why Worship? London: Independent Press Limited

Martin-Carey, Alexandra. 2016. "Between The Wars”, in Between The Wars: An Activist Novel. PhD Thesis, University of Kent. Canterbury: uk.bl.ethos.693834

Rollins, Peter. 2012. The Idolatry of God. London: Hodder and Stoughton

Solnit, Rebecca. 2014. "Woolf's Darkness: Embracing the Inexplicable.” In Men Explain Things to Me and Other Essays. London: Granta

Underhill, Evelyn. 2002. Mysticism. New York: Dover Publications Inc.

Wallis, Jill. 1993. Mother of World Peace; The life of Muriel Lester. Middlesex: Hisarlik Press. 